\title{
Design and Build Solar Panels as Source Rice Thresher Motor Energy
}

\author{
Trahman Sitepu, Ayu Tamara Malau, Cholish, \& Abdullah \\ Electrical Engineering Program, Electrical Engineering Department, Medan State Polytechnic, Medan, Indonesia \\ J1. Almamater No. 1, USU Medan Campus, 20155 \\ ${ }^{凶}$ Corresponding Author: trahman@polmed.ac.id| Phone: +628116321233
}

Received: September 8, 2021

Revision: September 16, 2021

Accepted: September 28, 2021

\begin{abstract}
Renewable energy generated from sunlight (Solar Panels) can be formed as alternative energy that can be applied to a source of electrical energy in rice thresher equipment. The use of solar energy with a power of 240 WP through the object on the rice thresher is able to replace the rice thresher automatically which is more effective. The power generated by solar energy will be processed into a charging source for the Regulated Battery Charger which can be supplied at a voltage to the control circuit to drive the DC motor. The average voltage generated by solar energy is 0.000394 volts/lux with a maximum voltage of 36.2 volts and a DC motor of 350 watts. In addition, the speed of this rice thresher is $950.8 \mathrm{rpm}$ and is able to produce very good rice cutting against the designed solar energy capabilities.

Keywords: solar panels; regulated battery chargers; dc motors;
\end{abstract}

\section{Introduction}

Rice is a food crop commodity that produces rice which plays an important role in the economic life of Indonesia. Namely rice as a staple food is very difficult to replace by other staples. Among them are corn, tubers, sago and other carbohydrate sources. So that the existence of rice becomes the main priority of the community in meeting the needs of carbohydrate intake which can be filling and is the main source of carbohydrates that are easily converted into energy. Rice as a food crop is consumed by approximately $90 \%$ of the total population of Indonesia for daily staple food (Donggulo et al., 2017).

One source of renewable energy that has not been used optimally is sunlight. With Indonesia's location at the equator, namely at $6 \mathrm{oLU}-11 \mathrm{oLS}$ and $95 \mathrm{oBT}-141 \mathrm{oBT}$ and by paying attention to the circulation of the sun in a year in the area of 23.5oLU and 23.5oLS, the territory of Indonesia will always be exposed to the sun for 10-12 hours a day. Baroken, 1991) with a high intensity of $5.1 \mathrm{kWH} / \mathrm{m}^{2} /$ day (Pangkung et al., 2013).

Batteries have become a part of modern life. The number of products that rely on batteries as a power source today is very large. For example, computers, cell phones, pacemakers, street vendors lighting, vehicles, which use batteries as a source of electricity. These devices use batteries that can normally be recharged. By using rechargeable batteries we provide two environmental and economic benefits (Hamid et al., 2016).

A direct current (DC) motor is a direct current machine that functions to convert electrical energy into mechanical energy. Direct current motors are widely used, especially in industrial parts that require large starting torque with constant acceleration and high efficiency (Harahap \& Nofriadi, 2019).

For this reason, this study will discuss based on the design of solar panels as a source of energy for rice threshing as a tool that is produced more efficiently, optimally and environmentally friendly according to the results of the desired provisions.

\section{Literature Review \\ Rice threshing}

Rice (Oryza sativa) is a rice-producing plant as the staple food of the Indonesian population. The increase in population growth is directly proportional to the demand for rice. Increased production can be done by expanding the rice planting area or by minimizing yield losses during the harvest or post-harvest process. Yield losses during harvest and postharvest handling can reach $20-21 \%$, occur in rice harvesting around $9 \%$ and in threshing around 5\% (Suhendra et al., 2019).

Rice threshing is the process of releasing rice grains from rice stalks so that they become separate (not fused). The principle of releasing rice grains from the stem is by applying pressure or hitting the object to the rice stalk.

\section{Solar Panel (Solar Cell)}

Solar panels (Solar Cells) or also often called photovoltaics are devices that are able to convert sunlight directly into electricity. Solar panels can be called the main actor to maximize the enormous potential of solar light energy that reaches the earth, although apart from being used to generate electricity, energy from the sun can also be maximized for its thermal energy through a solar thermal system (Aryza et al., 2017). 
The main difference from solar cell panels is the production material of the solar cell panels. The most common solar cell panel material is crystalline silicon, crystalline materials can consist of single crystal, mono or single-crystalline, and poly or multicristaline. In addition, there are solar cell panels made of a thin layer of Amorphous Silicon. Crystalline silicon cells have 2 types that are almost similar, although single crystalline cells are more efficient than poly-cristaline cells because poly-cristaline is a bond between cells. The advantage of amorphous silicon is that it is affordable but not as efficient as crystalline silicon solar cells (Solar et al., 2019).
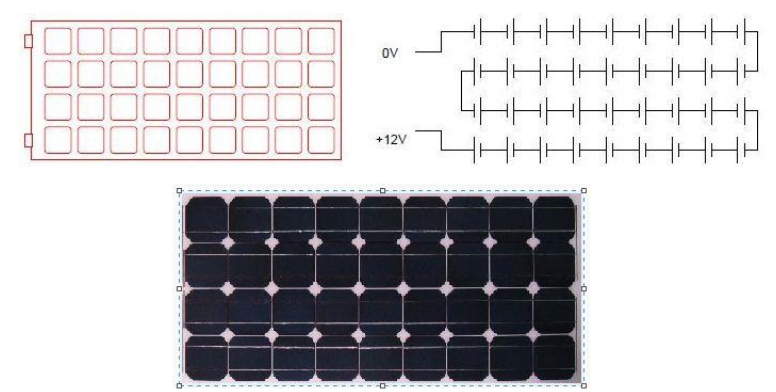

Figure 1. Solar Panel Module

Battery

A battery or accumulator is an electric cell in which a reversible electrochemical process takes place with high efficiency. What is meant by a reversible electrochemical reaction is that in the battery there can be a chemical conversion process into electric power (discharging process) and vice versa from electric power into chemical energy (charging process) by means of a regeneration process from the electrodes used, namely, by passing an electric current in the battery. opposite polarity in the cell. Batteries generate electricity through a chemical process (Thowil Afif \& Ayu Putri Pratiwi, 2015).

Batteries have two types of use namely Primary Batteries and Secondary Batteries. The use of Primary Batteries as usage that can only be used once, while the use of Secondary Batteries as usage that can be used repeatedly (the opposite).

\section{Battery Charger Regulated (BCR)}

Battery Charger Regulated is an electronic device which functions as a direct current regulator which is charged to the battery and taken from the battery to the load. Regulated battery charger is a means of regulating over charging (overcharging). Overcharging will reduce the life of the battery. This Regulated Battery Charger applies Pulse Width Modulation (PWM) technology.

Pulse Width Modulation (PWM) is a way of manipulating the width of the signal expressed by pulses in a period. Some examples of PWM applications are data modulation for telecommunications, controlling the power or voltage that enters the load, voltage regulators, audio effects and gains as well as other applications. Microcontroller-based PWM applications are usually in the form of controlling the speed of DC motors, Servo Motors, setting the LED bright flame (Azmi \& Tumangger, 2018).

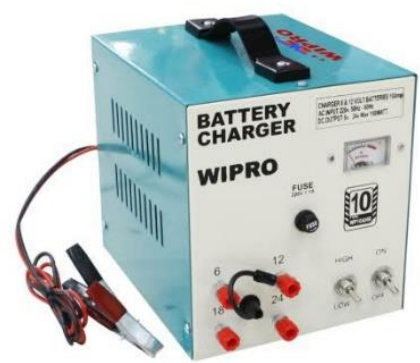

\section{Motor (Direct Current)}

Figure 2. Battery Charger Regulated (BCR)

DC motors require a direct voltage supply to the field coil to be converted into mechanical energy. In a dc motor there are two coils, namely the field coil which functions to produce a magnetic field and the anchor coil which functions as a place for the formation of an electromotive force (emf E). If the current in the armature coil interacts with the magnetic field, a torque (T) will arise which will rotate the motor (Nugroho \& Agustina, 2013).

The use of DC motors requires a direct voltage supply to the field coil to be converted into mechanical energy which is usually called the stator (non-rotating part) and the armature coil is called the rotor (rotating part). 


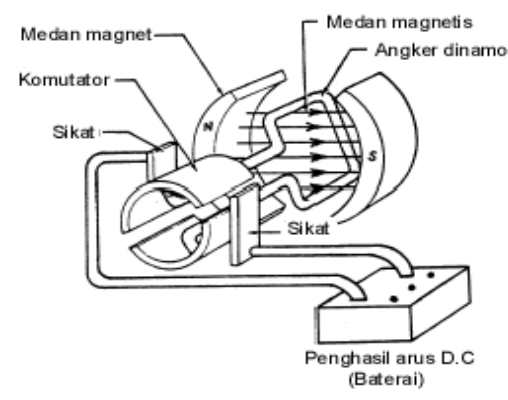

Figure 3. DC Motor

\section{Materials \& Methods}

Construction Design

Based on the design of the construction of the tool through the planning of the framework to support all the loads or components that will be placed on the framework, as seen in the following construction drawings.
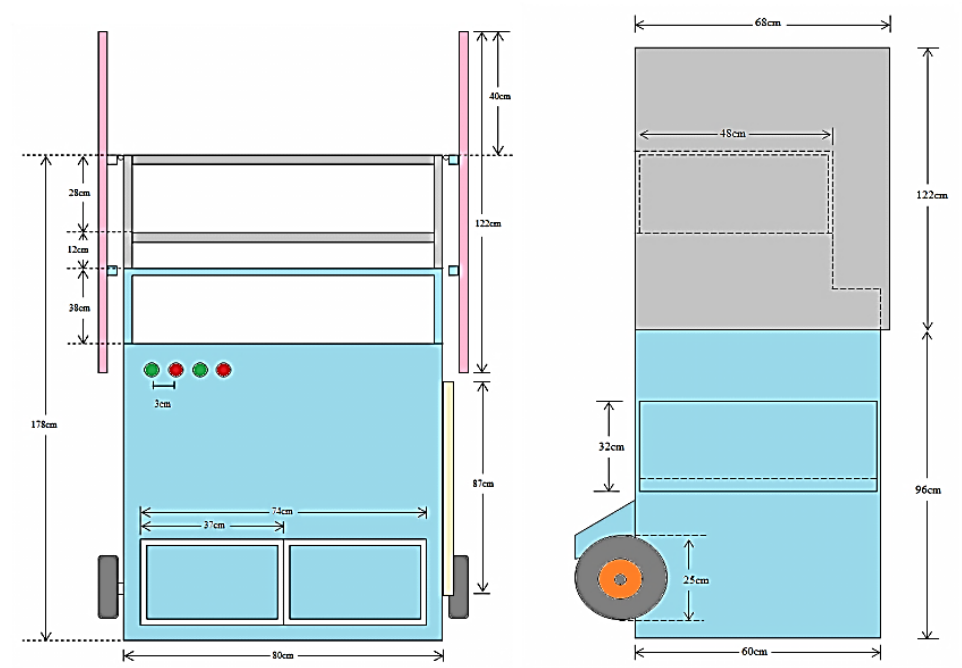

Figure 4. Front and Left View Construction

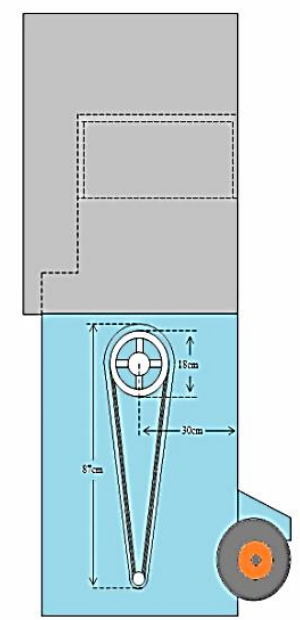

Figure 5. Construction Side View Right 


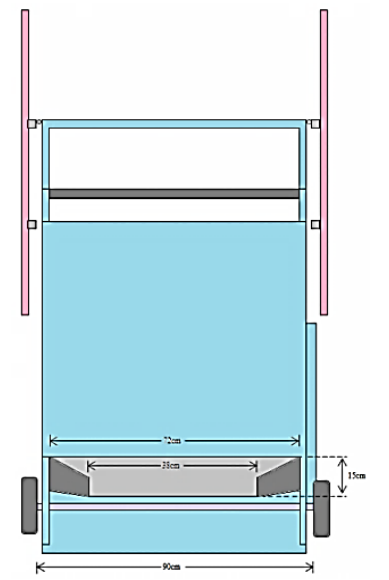

Figure 6. Rear View Construction

Systematics Design System

Based on the systematic design of the system in designing tools for rice threshing using solar panels, the stages in starting the design are as follows :

1. Determination of the dimensions of the support system that is planned to have a length of $80 \mathrm{~cm}$, a width of 60 $\mathrm{cm}$, and a height.

2. Determination of the specifications of the DC motor that is planned to have a voltage of 24 volts DC with a rotational speed of $2750 \mathrm{rpm}$.

3. Determination of solar panel power and battery capacity as a system supplier that is planned to have $240 \mathrm{wp}$ and a voltage of 24 volts DC.

\section{System Block Diagram}

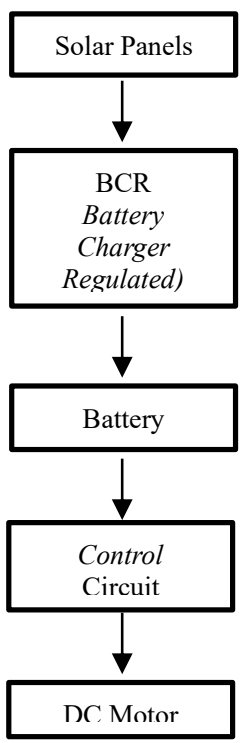

Figure 7. System Block Diagram

\section{Information :}

1. Solar Panel, functions as a converter of solar energy into electrical energy with the capacity of the solar panel used is $240 \mathrm{WP}$ and the output voltage of the solar panel depends on the intensity of light.

2. Regulated Battery Charger (BCR), functions as a controller for charging (charging) - discharging (released) battery power and has the main function as battery protection.

3. Battery, functions as a store of electrical power or the amount of energy that can be stored and released by the battery which is expressed in ampere hours (Ah).

4. Control circuit, functions as a controller of the system to control the motor.

5. DC Motor, serves as a driving cylinder thresher (drum rotating) to separate or thresh rice from the stalk. Diagram Flowchart System

Based on the system flowchart diagram in designing tools for rice threshing using solar panels, as for the work steps and processes on the tool as shown below. 


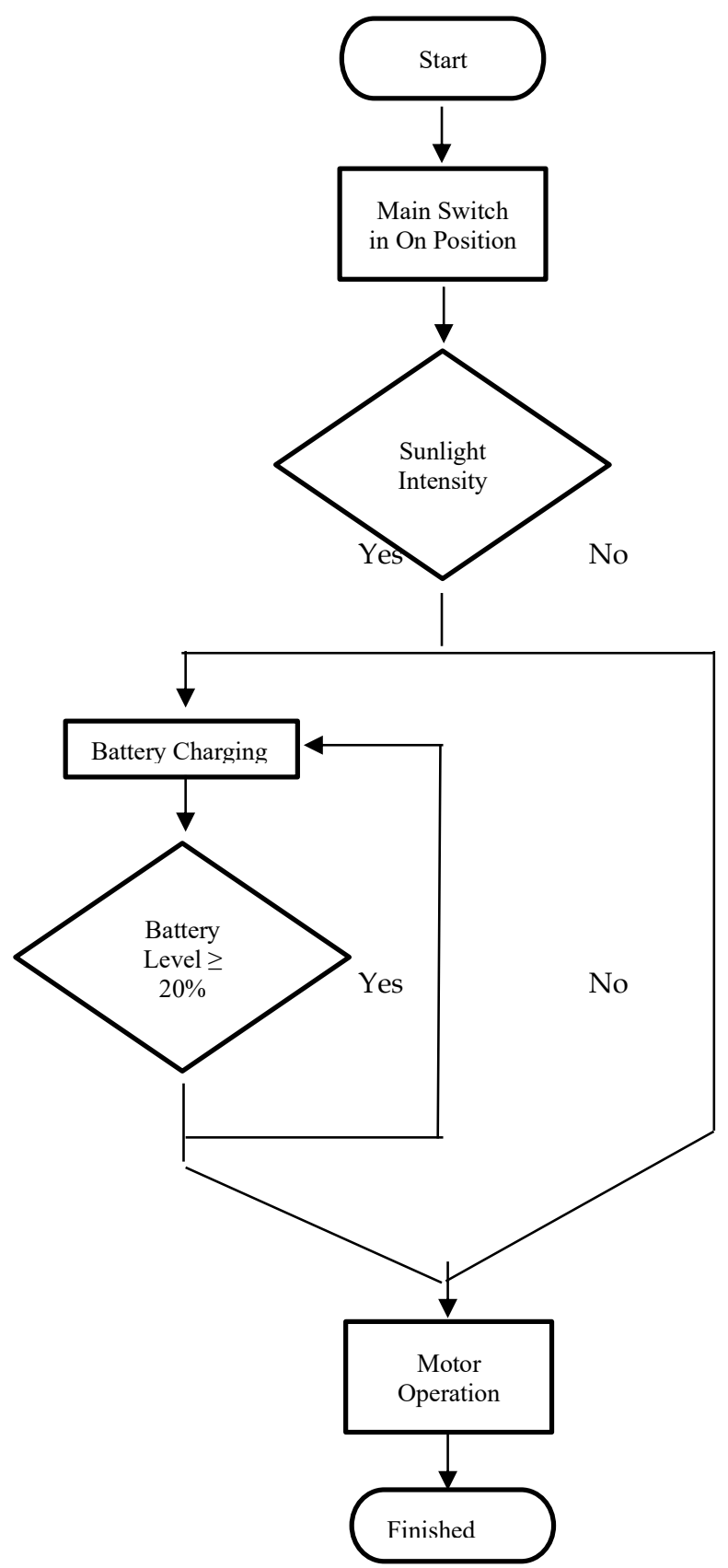

Figure 8. System Diagram Flowchart

The description of the picture, starting from the start is the beginning of the process, then when the main switch is in the on position then the next depends on the condition of the light intensity, if there is light it will charge the battery, if there is no light then nothing happens but can still operate motor with energy capacity from battery. Then if the battery is less than $20 \%$, then it is required to charge the battery first, while if it is more than $20 \%$ it is permissible to operate the motor and then the motor will work normally.

\section{System Working Principle}

The working principle of the system is as follows:

1. The battery charging process can only be done if the solar panel gets enough sunlight to channel its power to the battery through the BCR (Battery Charger Regulated).

2. The process of operating the motor, which is carried out by a control circuit that is arranged in such a way that it can turn on or stop the work of the motor.

\section{Network Image}

The whole circuit can be seen in the following figure. 


\section{ELECTRICAL DIAGRAM}
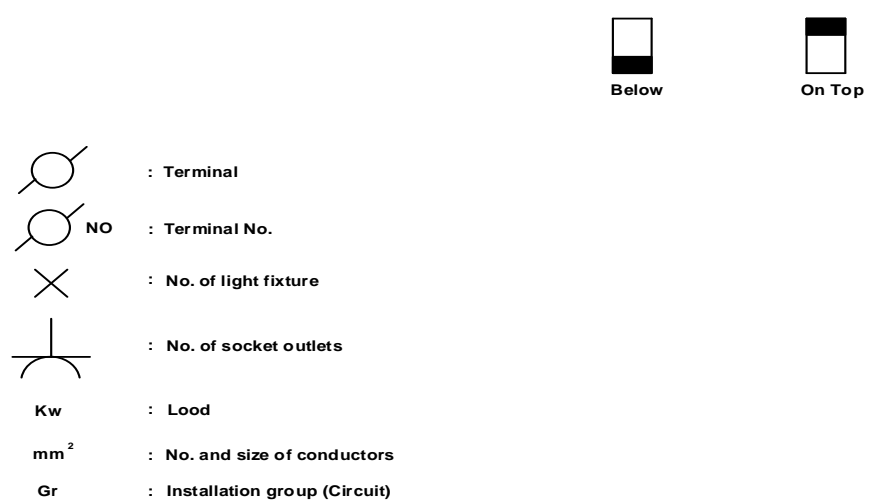

(S2) : Apparatus (example S2) mounted in panel front

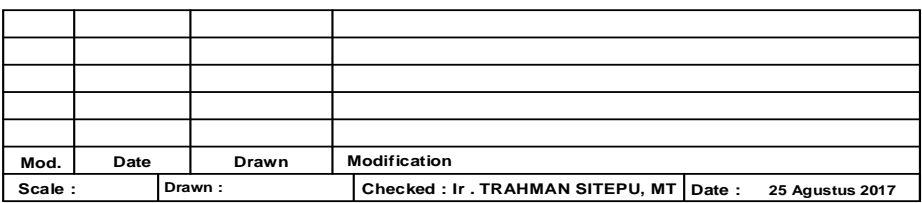

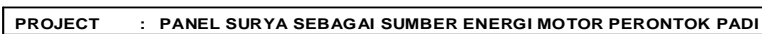

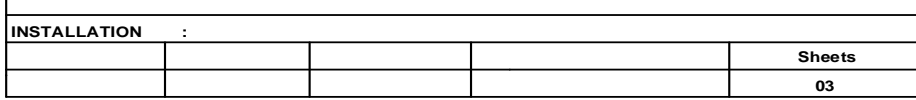

POLITEKNIK NEGERI MEDAN

Figure 9. Cover Diagram

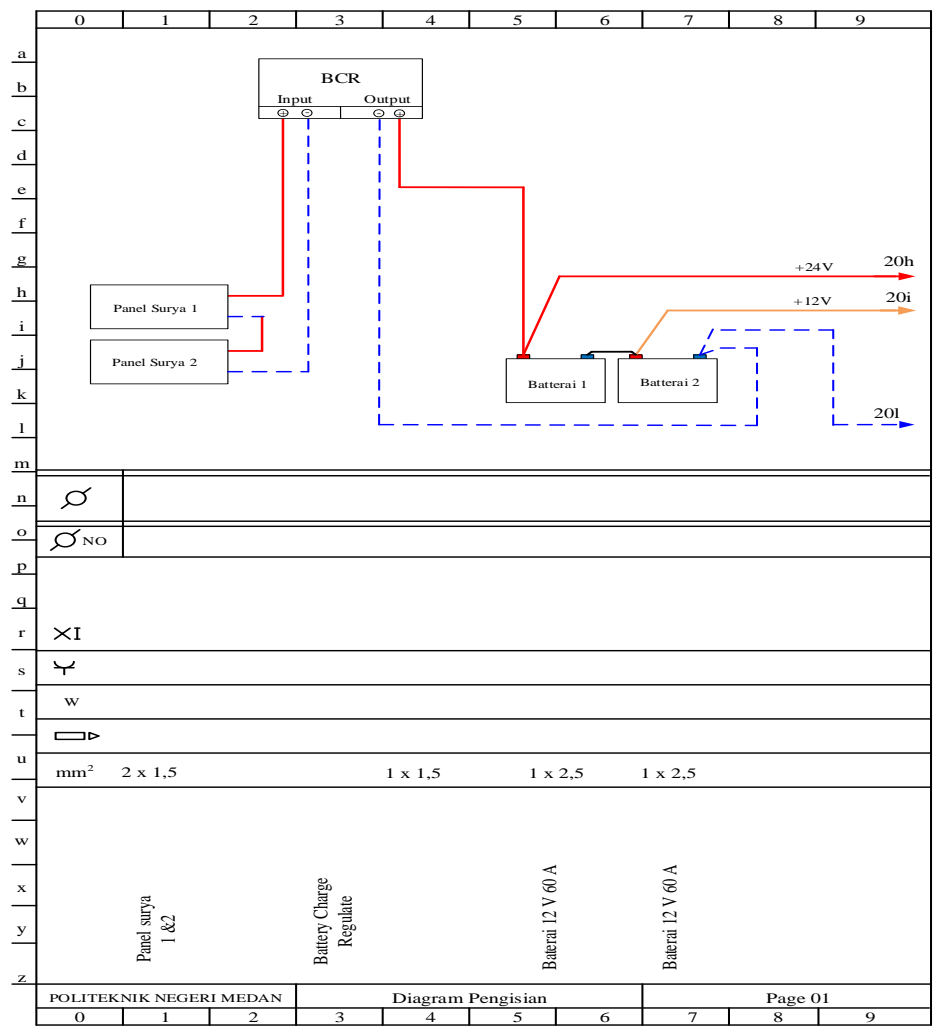

Figure 10. Battery Charge Chart 


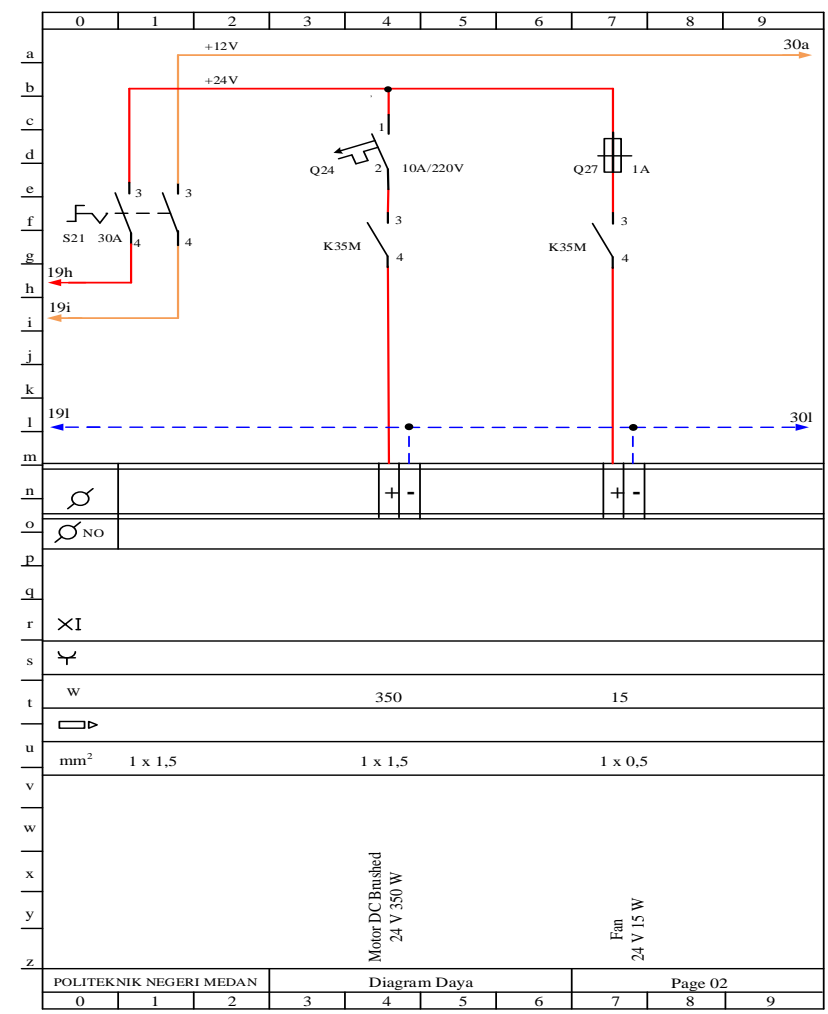

Figure 11. Power Diagram

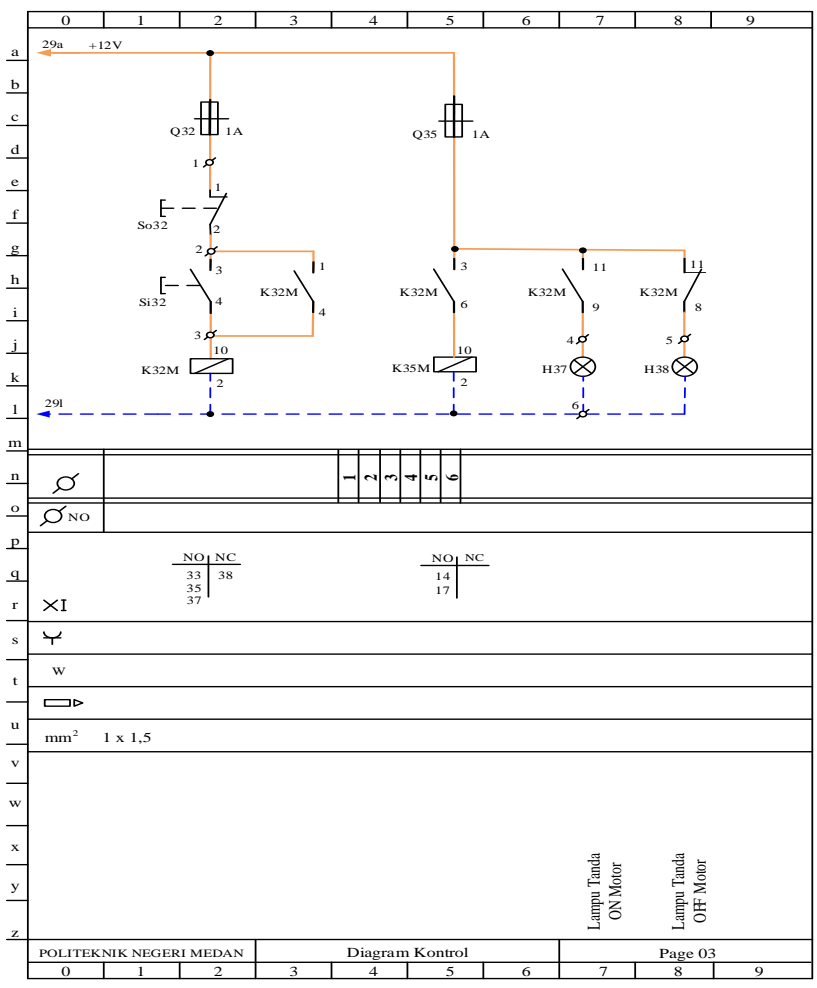

Figure 12. Control Chart

\section{How The Circuit Works}

The Solar Panel converts the amount of solar light energy into electrical energy which is channeled to the Regulated Battery Charge, then the Regulatory Battery charger lowers the voltage obtained from the solar panel and channeled it to the battery for charging.

Main switch S21 is the main switch in the circuit. When the main switch is operated, the circuit will be in standby position, and at that time the off condition H38 light is on because it is connected directly to the NC relay K32M auxiliary contact, then this indicates the circuit is ready to operate and the motor is off.

Then when the Si32 button is pressed, the circuit will be closed and the K32M relay will be energized and close all auxiliary contacts for $\mathrm{NO}$ contacts and open auxiliary contacts for NC contacts. 
1. Auxiliary contact $\mathrm{NO}$ on page 3 column 3 will lock the K32M relay.

2. Auxiliary contact $\mathrm{NO}$ on page 3 column 5 will operate the K35M relay.

3. Auxiliary contact $\mathrm{NO}$ on page 3 column 7 will operate the $\mathrm{H} 28$ indicator light or indicate that the motor and cooling fan are operating.

4. The NC auxiliary contact on page 3 column 8 will open so that the $\mathrm{H} 29$ indicator light is Off.

Then the energized K35M relay and its auxiliary contacts on page 2 columns 4 and 7 will close the circuit so that the brushed DC motor and cooling fan operate.

Then when the So32 pushbutton is pressed, the circuit will open and the K32M relay will turn off and open all auxiliary contacts for $\mathrm{NO}$ contacts and close auxiliary contacts for NC contacts.

1. Auxiliary contact $\mathrm{NO}$ on page 3 column 3 will unlock the $\mathrm{K} 32 \mathrm{M}$ relay so that the relay is off.

2. The NO auxiliary contact on page 3 column 5 will unlock the $\mathrm{K} 35 \mathrm{M}$ relay, then the DC motor and fan will be off.

3. The NO auxiliary contact on page 3 column 7 will open so that the $\mathrm{H} 37$ indicator light is Off or indicates that the motor and cooling fan are Off.

4. The NC auxiliary contact on page 3 column 8 will close so that the H38 On light indicates the system is in standby.

\section{Results and Discussion}

Testing of Solar Panels and BCR

Table 1. Testing of Solar Panels and Regulated Battery Chargers

\begin{tabular}{|c|c|c|c|c|c|c|c|}
\hline \multirow[b]{2}{*}{ No. } & \multirow[b]{2}{*}{ Time (At) } & \multirow[b]{2}{*}{$\begin{array}{l}\text { Light intensity } \\
\text { (lux) }\end{array}$} & \multicolumn{2}{|c|}{ Solar Panel Output } & \multicolumn{2}{|c|}{ BCR Output } & \multirow{2}{*}{$\begin{array}{c}\text { Battery } \\
\text { Voltage } \\
\text { (volt) }\end{array}$} \\
\hline & & & Voltage (volt) & $\begin{array}{c}\text { Current } \\
\text { (ampere) }\end{array}$ & $\begin{array}{c}\text { Voltage } \\
\text { (volt) }\end{array}$ & $\begin{array}{c}\text { Current } \\
\text { (ampere) }\end{array}$ & \\
\hline 1 & $10: 00$ & 79.800 & 26,58 & 5,26 & 26,83 & 3,55 & 25,61 \\
\hline 2 & $10: 30$ & 85.500 & 30,97 & 5,6 & 26,88 & 3,99 & 25,73 \\
\hline 3 & $11: 00$ & 86.900 & 32,29 & 5,94 & 26,94 & 4,31 & 25,82 \\
\hline 4 & $11: 30$ & 93.100 & 33,44 & 6,08 & 26,93 & 4,44 & 25,93 \\
\hline 5 & $12: 00$ & 99.400 & 34,22 & 6,44 & 26,93 & 4,64 & 25,96 \\
\hline 6 & $12: 30$ & 103.500 & 36,2 & 6,34 & 26,92 & 4,78 & 26,06 \\
\hline 7 & $13: 00$ & 97.200 & 35,76 & 6,13 & 26,93 & 4,62 & 26,17 \\
\hline 8 & $13: 30$ & 93.300 & 35,42 & 5,85 & 26,82 & 4,57 & 26,25 \\
\hline 9 & $14: 00$ & 92.500 & 35,34 & 5,3 & 26,82 & 4,46 & 26,35 \\
\hline 10 & $14: 30$ & 81.000 & 35,22 & 5,12 & 26,82 & 4,01 & 26,41 \\
\hline 11 & $15: 00$ & 76.500 & 34,12 & 4,33 & 26,77 & 3,66 & 26,43 \\
\hline 12 & $15: 30$ & 64.300 & 32,59 & 3,96 & 26,76 & 2,72 & 26,44 \\
\hline 13 & $16: 00$ & 54.500 & 26,38 & 2,1 & 26,34 & 1,42 & 26,44 \\
\hline \multicolumn{2}{|c|}{ Maximum } & 103500 & 36,2 & 6,44 & 26,94 & 4,78 & 26,44 \\
\hline \multicolumn{2}{|c|}{ Minimum } & 54.500 & 26,38 & 2,1 & 26,34 & 1,42 & 25,61 \\
\hline \multicolumn{2}{|c|}{ Average } & 85.192 & 32,89 & 5,27 & 26,82 & 3,94 & 26,12 \\
\hline
\end{tabular}

Based on the table, the solar panels were tested starting at 10.00 WIB until 16.00 WIB with the angle between the solar panel and the sun ranging from 30 o to the perpendicular side. The battery voltage is measured incrementally every 30 minutes, and the battery is in the open loop position.

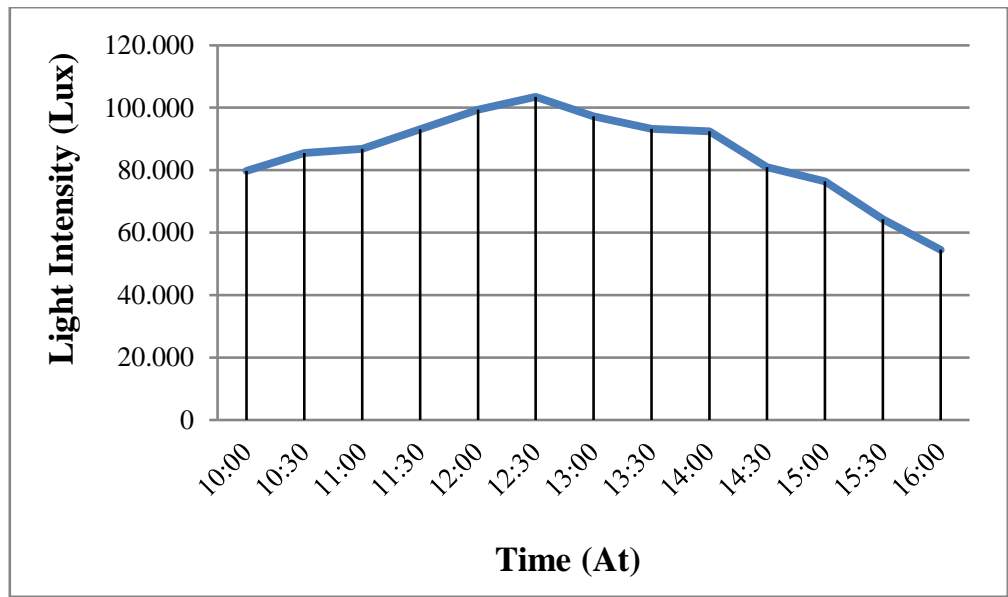

Figure 13. Light Intensity Graph by Time

Based on the picture, that shows a graph of light intensity based on time. At 10.00 the irradiation starts with an intensity of 79,800 lux, the morning begins with clear weather without clouds and at 16.00 the light intensity drops to 
54,500 lux when the angle of the sun with the surface of the solar panel is very small. The highest light was measured at 12.30 WIB with a total irradiation of 103,500 lux in very sunny and hot weather up to $38{ }^{\circ} \mathrm{C}$. The lowest light intensity was measured at 16.00 with a total irradiation of 54,500 lux.

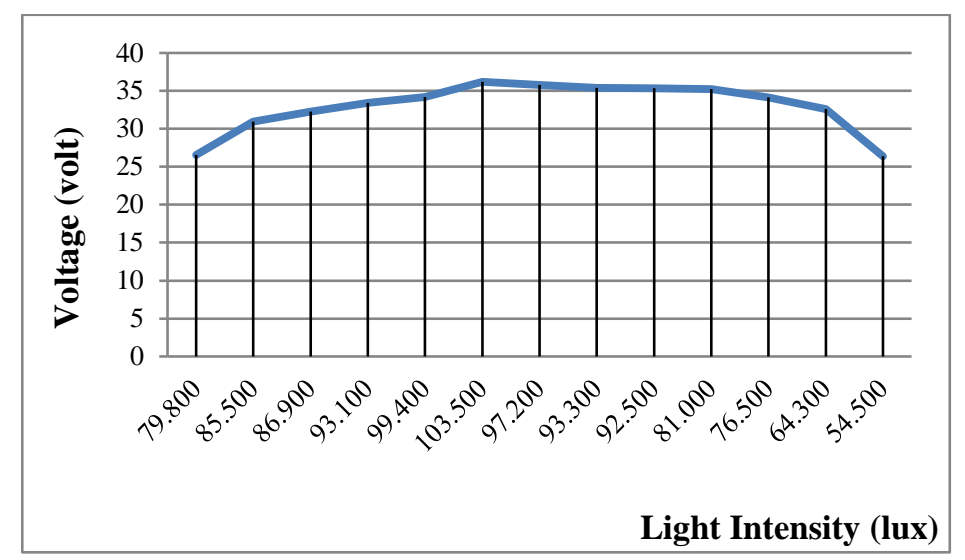

Figure 14. Graph of Solar Panel Output Voltage Against Light Intensity

Based on the figure, it shows a graph of the solar panel output voltage against light intensity, so that through this measurement data the maximum voltage produced by the solar panel is at $12.30 \mathrm{WIB}$, which is 36.2 volts when the light intensity is 103,500 lux. And the minimum voltage produced by the solar panels is at $16.00 \mathrm{WIB}$, which is 26.38 volts when the light intensity is 54,500 lux. The average voltage produced is 0.000394 volt/lux.

Table 2. Solar Panel Output Power and BCR Output Power For Battery Charging

\begin{tabular}{ccccc}
\hline No & $\begin{array}{c}\text { Time } \\
\text { (At) }\end{array}$ & $\begin{array}{c}\text { Solar Panel Output } \\
\text { Power (watt) }\end{array}$ & Power (watt) & $\begin{array}{c}\text { BCR Output } \\
\text { Efficiency (\%) }\end{array}$ \\
\hline 1 & $10: 00$ & 139,8108 & 95,2465 & 68,125 \\
2 & $10: 30$ & 173,432 & 107,2512 & 61,840 \\
3 & $11: 00$ & 191,8026 & 116,1114 & 60,536 \\
4 & $11: 30$ & 203,3152 & 119,5692 & 58,809 \\
5 & $12: 00$ & 220,3768 & 124,9552 & 56,701 \\
6 & $12: 30$ & 229,508 & 128,6776 & 56,066 \\
7 & $13: 00$ & 219,2088 & 124,4166 & 56,757 \\
8 & $13: 30$ & 207,207 & 122,5674 & 59,152 \\
9 & $14: 00$ & 187,302 & 119,6172 & 63,863 \\
10 & $14: 30$ & 180,3264 & 107,5482 & 59,640 \\
11 & $15: 00$ & 147,7396 & 97,9782 & 66,318 \\
12 & $15: 30$ & 129,0564 & 72,7872 & 56,399 \\
13 & $16: 00$ & 55,398 & 37,4028 & 67,516 \\
Maximum & & 229,508 & 128,6776 & 68,125 \\
Minimum & & 55,398 & 37,403 & 56,067 \\
Average & & 175,730 & 105,702 & 60,902 \\
\hline
\end{tabular}

Based on the table, the maximum power that can be produced by solar panels is at 12.30 WIB which is 229.508 watts with a BCR output of 128.677 watts and the minimum power produced by solar panels is at 16.00 WIB with a power of 55.398 watts with a BCR output power of 37,4028 watts.

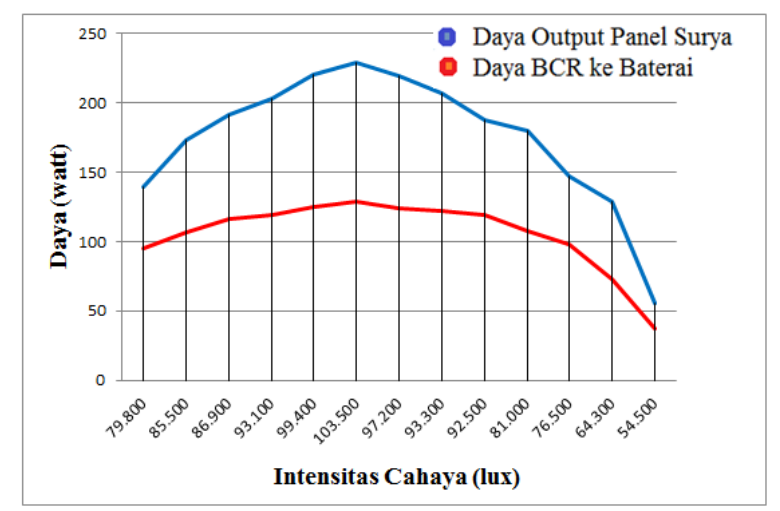

Figure 15. Comparison Graph Between Solar Panel Power With Power On BCR 
Based on the picture, that shows the comparison between the power of the solar panel and the power on the BCR. The highest power that can be processed by BCR is $68.125 \%$ and the average power that can be processed by Battery Charge Regulated (BCR) from solar panels is $60.902 \%$. Thus, the efficiency of BCR is only $60.902 \%$.

\section{Battery Charging Test}

Through this battery test, that the battery has been charged 2 bars out of a total of 4 bars (the battery has been charged $2 / 4$ in total) displayed on the BCR screen. And at 16.00 WIB the battery charging has reached $4 / 4$ bar.

Table 3. Battery Charging Test

\begin{tabular}{ccccc}
\hline \multirow{2}{*}{ BCR Output Current } & \multicolumn{2}{c}{ Time } & Charged Current \\
\cline { 2 - 5 } & Beginning & End & Duration & (Ah) \\
\hline 3,55 & (At) & (At) & (Minute) & 1,775 \\
\hline 3,99 & $10: 00: 00$ & $10: 30: 00$ & 30 & 1,995 \\
\hline 4,31 & $10: 30: 00$ & $11: 00: 00$ & 30 & 2,155 \\
\hline 4,44 & $11: 00: 00$ & $11: 30: 00$ & 30 & 2,22 \\
\hline 4,64 & $11: 30: 00$ & $12: 00: 00$ & 30 & 2,32 \\
\hline 4,78 & $12: 00: 00$ & $12: 30: 00$ & 30 & 2,39 \\
\hline 4,62 & $12: 30: 00$ & $13: 00: 00$ & 30 & 2,31 \\
\hline 4,57 & $13: 00: 00$ & $13: 30: 00$ & 30 & 2,23 \\
\hline 4,46 & $13: 30: 00$ & $14: 00: 00$ & 30 & 2,005 \\
\hline 4,01 & $14: 00: 00$ & $14: 30: 00$ & 30 & 1,83 \\
\hline 3,66 & $14: 30: 00$ & $15: 00: 00$ & 30 & 1,36 \\
\hline 2,72 & $15: 00: 00$ & $15: 30: 00$ & 30 & 0 \\
\hline Average & $15: 30: 00$ & $16: 00: 00$ & 30 & 24,875 \\
\hline & $16: 00: 00$ & $16: 00: 00$ & 0 & 3,936 \\
\hline & & & & \\
\hline
\end{tabular}

Based on the table, the current charged to the battery from $10.00 \mathrm{WIB}$ to $16.00 \mathrm{WIB}$ is $24.875 \mathrm{Ah}$. The highest current produced by BCR is 4.78 amperes at $12.30 \mathrm{WIB}$, and the lowest current is 1.42 amperes at $16.00 \mathrm{WIB}$.

Through this experiment, charging batteries using solar panels is only effective from 10.00 WIB to 15.00 WIB or only lasts for 5 hours of charging per day. With an average battery charging through the BCR of 3,936 amperes.

On charging a 24 volt battery, the BCR emits an average voltage of 26.82 volts. The voltage in the charging process is given $111.766 \%$ of the battery voltage.

Calculation of battery charging time using equation (2) :

$$
\begin{aligned}
\mathrm{t} & =\left(\frac{C}{\mathrm{I}}+\emptyset 1\right) \\
\mathrm{t} & =\left(\frac{60}{3,936}+\emptyset 1\right) \\
& \mathrm{t}=(15,243+(0,2 \times 15,243)) \\
\mathrm{t} & =(15,243+3,048) \\
\mathrm{t} & =18,291 \text { jam }
\end{aligned}
$$

So that it takes 18,291 hours to fully charge the battery for an average charging current of 3,936 amperes from 10.00 WIB to 16.00 WIB. So to fully charge the battery it takes 3 days to charge 6 hours a day.

\section{Battery Test Against Motor}

The use of testing on battery power for the motor has 212 Volt Lead acid dry batteries which are arranged in series as a power storage from the solar cell. The stored power will be used to start the 350 watt brushed DC motor. So, for calculations on battery usage and charging can be obtained with the following calculations:

Is known : Burden $=350 \mathrm{~W}$

Battery used $=24 \mathrm{~V} ; 60 \mathrm{Ah}$.

Asked : How long the battery can supply burden?

Solution :

Motor current : 


$$
\begin{aligned}
& I=\frac{P}{V} \\
& I=\frac{350}{24} \\
& I=14,583 \text { ampere } \\
& \quad \text { Loading time : } \\
& t=\frac{60}{14,583} \\
& t=4,114 \text { hours }
\end{aligned}
$$

Because the battery has a minimum capacity that must be left on the battery (efficiency) of $20 \%$, the loading time is reduced during:

$$
\begin{aligned}
& t=4,114 \times 0,2 \\
& t=0,8228 \text { hours }
\end{aligned}
$$

Thus the motor can only be loaded as long as :

$$
\begin{aligned}
& t=4,114-0,8228 \\
& t=3,2912 \text { hours }
\end{aligned}
$$

\section{Fan Testing (Fan)}

In this test, the fan requires $0.41 \mathrm{~A}$ of power with a voltage of $24 \mathrm{VDC}$ to operate at full speed. So the fan only absorbs 9.84 watts of power.

\section{Brushed DC Motor Temperature Testing}

Table 4. Brushed DC Motor Temperature Testing With Thresher Cylinder

\begin{tabular}{cc} 
Time & Temperature \\
(Minute) & ('C) \\
\hline 1 & 34,5 \\
6 & 34,8 \\
9 & 35,2 \\
12 & 35,8 \\
15 & 36,5 \\
18 & 37 \\
21 & 37,2 \\
24 & 38,1 \\
27 & 38,5 \\
30 & 38,8 \\
33 & 39 \\
36 & 40,1 \\
39 & 40,6 \\
42 & 40,9 \\
45 & 41,3 \\
48 & 42,3 \\
51 & 42,7 \\
54 & 43 \\
57 & 43,8 \\
60 & 44,7 \\
\hline
\end{tabular}

Based on the following table, the motor test was carried out for one hour when the temperature around the brushed $\mathrm{DC}$ motor was $34.2^{\circ} \mathrm{C}$, and the outside temperature of the rice thresher was $35.1{ }^{\circ} \mathrm{C}$.

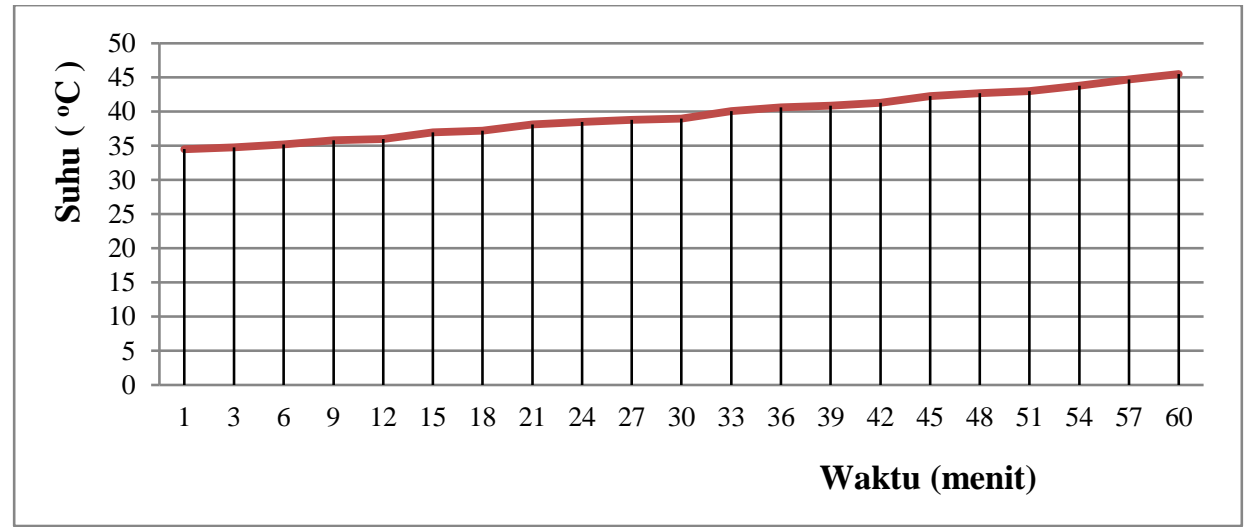

Figure 16. Motor Temperature Graph In One Hour Of Operation 
Based on the following picture, that shows a picture of the Motor Temperature Graph in One Hour of Operation. Through this measurement, it is concluded that the motor temperature is getting higher when it is operated for longer. Therefore the motor must be immediately cooled by turning off the motor, and the fan continues to run to cool the motor, it takes 20 minutes for the motor temperature to drop to $34.3^{\circ} \mathrm{C}$.

\section{Thresher Cylinder Speed Test}

The use of this thresher cylinder speed test results in measurements using a tacho meter measuring instrument, the measured speed of the threshing cylinder is $950.8 \mathrm{rpm}$. And the speed of a DC motor with a 2 inch pulley is measured at $3368 \mathrm{rpm}$.

\section{Rice Thresher Test}

The use of this rice thresher test was carried out in farmers' fields in Suka Sari Village, Galang District, Deli Serdang Regency, North Sumatra.

The measurement data on rice threshing as much as $30 \mathrm{~kg}$, as follows :

1. The battery, which was previously rated at 25.73 volts.

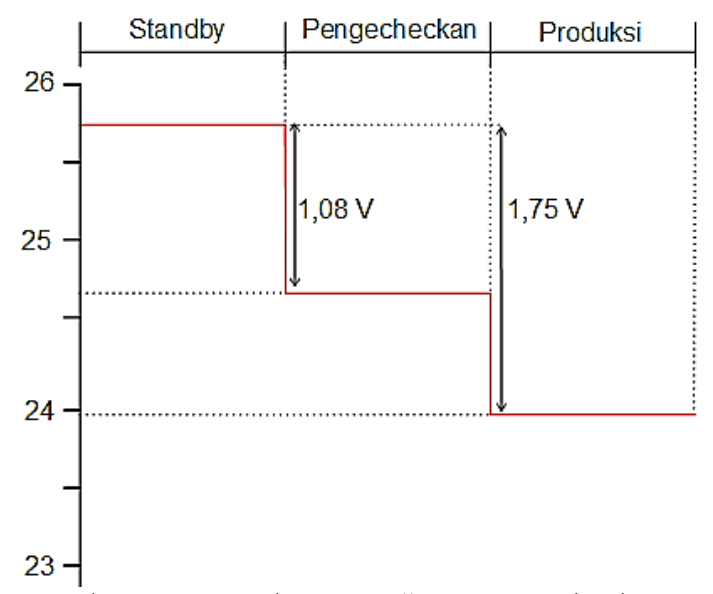

Figure 18. Battery Voltage Drop When Standby During Checking And Production

Based on the picture, that the Battery Voltage Drop when Standby, Checking and During Production. When the DC motor and fan are turned on at no load (not yet doing rice threshing activities) the voltage drops to 24.65 volts, and when the rice is threshed the voltage drops to 23.98 volts. After the threshing activity is carried out for 14 minutes and the DC motor is turned off, the voltage on the battery drops to 25.41 volts, there is a decrease in battery voltage of 0.32 volts due to reduced battery capacity.

2. DC motor, when carrying out the activity is $33.6^{\circ} \mathrm{C}$ and the temperature on the $\mathrm{DC}$ motor is measured at $33.1{ }^{\circ} \mathrm{C}$ and after doing the rice threshing activity for 14 minutes the temperature on the motor rises to $38.3{ }^{\circ} \mathrm{C}$.

3. Production Results.

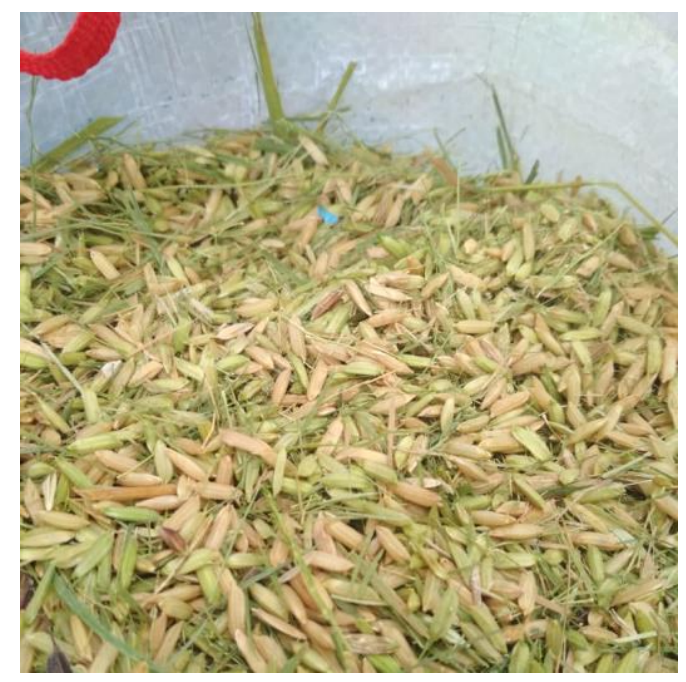

Figure 19. Grain That Has Been Threshed 


\section{Conclusions}

The highest intensity of sunlight was measured at 12.30 WIB with a total light intensity of 103,500 lux with a voltage of 36.2 volts and the lowest intensity of sunlight was measured at 16.00 with a total irradiation of 54,500 lux with a voltage of 26.38 volts. The highest power generated by solar panels is at $12.30 \mathrm{WIB}$ with an output power of 224,119 watts and the minimum power produced by solar panels is at 16.00 WIB with a power of 55.398 watts and BCR efficiency is $60.902 \%$. It takes 18.5 hours to fully charge the battery if the average BCR output current is 3.89 amperes when using a $240 \mathrm{WP}$ solar panel from 10.00 WIB to 16.00 WIB. A fully charged battery can operate the motor for approximately 3.3 hours.

The production capacity reaches $100 \mathrm{~kg} /$ hour, when compared to the traditional rice thresher which is only $50 \mathrm{~kg}$ /hour, this rice thresher machine is 2 times superior.

\section{References}

Aryza, S., Hermansyah, H., Siahaan, A. P. U., Suherman, S., \& Lubis, Z. (2017). Implementasi Energi Surya Sebagai Sumber Suplai Alat Pengering Pupuk Petani Portabel. It Journal Research and Development, 2(1), 12-18. https://doi.org/10.25299/itjrd.2017.vol2(1).642.

Azmi, Z., \& Tumangger, J. (2018). Implementasi Pulse Width Modulation Untuk Sistem Pembuat Mie. 2(1), $20-24$.

Donggulo, C. V., Lapanjang, I. M., \& Made, U. (2017). Pertumbuhan dan hasil tanaman padi (Oryza sativa L) pada berbagai pola jajar legowo dan jarak tanam. J. Agroland, 24(1), 27-35.

Hamid, R. M., Rizky, R., Amin, M., \& Dharmawan, I. B. (2016). Rancang Bangun Charger Baterai Untuk Kebutuhan UMKM. JTT (Jurnal Teknologi Terpadu), 4(2), 130. https://doi.org/10.32487/jtt.v4i2.175.

Harahap, R., \& Nofriadi, S. (2019). Analisa Perbandingan Efesiensi Dan Torsi Dengan Menggunakan Metode Penyadapan Sejajar Terhadap Metode Pergeseran Sikat Pada Motor Arus Searah Kompon Pendek Dengan Kutub Bantu. 4(3).

Nugroho, N., \& Agustina, S. (2013). Perancangan Setting Rele Proteksi Arus Lebih Pada Motor Listrik Industri. Transmisi, 15(1), 40-46. https://doi.org/10.12777/transmisi.15.1.40-46.

Pangkung, A., Yunus, A. M. S., \& Ala, O. (2013). Tenaga Surya Sebagai Penggerak Propeller Pada Perahu Nelayan. Pangkung, A., Yunus, A. M. S., Ala, O. (2013). T.

Solar, P., Sebagai, C., \& Energi, S. (2019). Listrik Alternatif Untuk Penerangan Lobby Fakultas. 2(2), $151-157$.

Suhendra, S., Muliadi, M., Syahrizal, I., \& Rianto, A. (2019). Kajian Eksperimen Kapasitas dan Efisiensi Perontokan pada Power Thresher dengan Variasi Kecepatan Putar dan Jumlah Gigi Silinder Perontok. Turbo : Jurnal Program Studi Teknik Mesin, 8(1). https://doi.org/10.24127/trb.v8i1.913.

Thowil Afif, M., \& Ayu Putri Pratiwi, I. (2015). Analisis Perbandingan Baterai Lithium-Ion, LithiumPolymer, Lead Acid dan Nickel-Metal Hydride pada Penggunaan Mobil Listrik - Review. Jurnal Rekayasa Mesin, 6(2), 95-99. https://doi.org/10.21776/ub.jrm.2015.006.02.1 